\title{
Penerapan asuhan keperawatan dalam kebutuhan mobilitas fisik pada rheumatoid arthritis di puskesmas tamalate makassar
}

\author{
Muhammad Purqan Nur
}

Fakultas Kedokteran Dan Ilmu Kesehatan Universitas Muhammadiyah Makassar

\section{Keywords :}

Askep, oxygenation, Tuberculosis

\section{Kontak :}

Muhammad Purqan Nur

Email :

muhammad.purqan@unismuh.ac.id

Fakultas Kedokteran Dan Ilmu

Kesehatan Universitas Muhammadiyah

Makassar

Vol 2 No 1 September 2019

DOI:

https://doi.org/10.31605/jhealt.v2i1

C)2019J-Healt

ini adalah artikel dengan akses terbuka dibawah licenci CC BY-NC-4.0

https://creativecommons.org/licenses/by-nc/4.0/

\begin{abstract}
Abstrak
Penyakit kronis dapat dikatakan sebagai salah satu beban ganda dibidang kesehatan. beberapa penyakit kronis salah satunya adalah rheumatoid arthritis. Reumatoid artritis memberikan dampak negatif yang signifikan terhadap kemampuan beraktivitas, baik suatu pekerjaan ataupun tugas dalam rumah tangga dan mempengaruhi kualitas hidup serta meningkatkan angka kematian. Diperkirakan angka ini terus meningkat hingga tahun 2025 dengan indikasi dari 25\% akan mengalami kelumpuhan. Penelitian ini bertujuan menggambarkan penerapan asuhan keperawatan pada pasien rheumatoid arthritis dalam pemenuhan kebutuhan mobilitas fisik. Penelitian menggunakan metode deskriptif dengan pendekatan studi kasus pada pasien yang mengalami rheumatoid arthritis dalam pemenuhan kebutuhan mobilitas fisik. Data dianalisis berdasarkan hasil wawancara dan observasi yang didapatkan pada saat penelitian. Setelah dilakukan tindakan keperawatan Selama tiga hari, pasien mengatakan masih sulit melakukan aktivitas karena masih merasakan sakit pada sendi kaki kiri. setelah menentukan prioritas masalah berdasarkan hasil pengkajian, maka dilakukan tindakan keeprawatan selama tiga hari dan hasilnya Tn.A sudah bias menggerakkannya sedikit demi sedikit dengan bantuan keluarga. Dengan melakukan latihan range of motion aktif dan pasif secara rutin akan membantu dalam mengurangi gangguan mobilitas fisik.
\end{abstract}

\begin{abstract}
Chronic illness can be said as one of the double burdens in the health sector. some chronic diseases one of which is rheumatoid arthritis. Rheumatoid arthritis has a significant negative impact on the ability to move, both work and household duties and affects the quality of life and increases mortality. It is estimated that this number continues to increase until 2025 with an indication of $25 \%$ will experience paralysis. This study aims to describe the application of nursing care to rheumatoid arthritis patients in meeting physical mobility needs. The study used a descriptive method with a case study approach in patients experiencing rheumatoid arthritis in meeting their physical mobility needs. Data were analyzed based on the results of interviews and observations obtained at the time of the study. After the nursing action was carried out for three days, the patient said it was still difficult to do the activity because he still felt pain in the left leg joint. after determining the priority of the problem based on the results of the assessment, then a three-day keeprawatan was taken and the result was that Mr. A was able to move him little by little with the help of the family. By doing active and passive range of motion exercises on a regular basis will help in reducing impaired physical mobility.
\end{abstract}




\section{Pendahuluan}

Penyakit kronis dapat dikatakan sebagai salah satu beban ganda dibidang kesehatan. beberapa penyakit kronis antara lain seperti penyakit sendi atau rematik, hipertensi, diabetes mellitus, stroke, penyakit paru, penyakit jantung, dan kanker (Kementerian Kesehatan RI, 2013).

College of Rheumatology (2015), Reumatoid artritis memberikan dampak negatif yang signifikan terhadap kemampuan beraktivitas, baik suatu pekerjaan ataupun tugas dalam rumah tangga dan mempengaruhi kualitas hidup serta meningkatkan angka kematian (Singh et al, 2015). World Health Organization 2016 menyatakan bahwa Penderita reumatoid atritis diseluruh dunia sudah mencapai angka 335 juta, dan diperkirakan jumlah penderita rheumatoid atritis akan selalu mengalami peningkatan.

Rheumathoid arthiritis (RA) merupakan penyakit autoimun yang ditandai oleh inflamasi sistematik kronik dan progresif, dengan target utama adalah sendi. Sendi yang dikenai terutama sendi kecil dan menengah secara simetris. Rheumathoid arthriritis tidak hanya menngenai lapisan synovial sendi tetapi juga dapat mengenai organorgan diluar persendian sperti kulit, janting, paruparu, dan mata (Suarjana 2014).

Penderita rheumathoid arthritis pada lansia diseluruh dunia telah mencapai angka 355 juta jiwa,artinya 1 dari 6 lansia di dunia ini menderita rematik. Diperkirakan angka ini terus meningkat hingga tahun 2025 dengan indikasi dari 25\% akan mengalami kelumpuhan

Berdasarkan data di Puskesmas Tamalate pada bulan Januari-Desember 2018 tercatat laki-laki dan perempuan umur 35-76 tahun ke atas sebanyak 197 orang. Pada bulan JanuariDesember 2019 tercatat laki-laki umur 35-76 tahun ke atas sebanyak 223 orang yang mengalami penyakit Rheumathoid Artrhitis, dan kebanyakan data yang didapatkan adalah seorang lansia diatas umur 60an.

\section{Metode}

\section{Desain Penelitian}

Penelitian menggunakan metode deskriptif dengan pendekatan studi kasus dengan penerapan asuhan keperawatan pada pasien yang mengalami rheumatoid arthritis dengan kebutuhan mobilitas fisik.

\section{Tempat dan Waktu}

Penelitian ini dilaksanakan di Wilayah Kerja Puskesmas Puskesmas Tamalate Kota Makassar pada tanggal 15 s/d 17 Juni 2019

\section{Sampel}

Adapun subjek studi kasus adalah pasien lansia yang mengalami rematik dengan kebutuhan mobilitas fisik pada ektermitas bawah, dan bersedia menjadi subjek penelitian.

\section{Instrumen Studi Kasus}

Adapun tekhnik pengumpulan data dengan cara melakukan wawancara dan observasi kepada pasien

\section{Etika Pengambilan data}

Dalam penelitian studi kasus perlu ada rekomendasi institusi dengan mengajukan surat permohonan izin kepada institusi atau lembaga yang ditempati untuk melaksanakan studi kasus. Selain itu, dalam melakukan studi kasus tetap memperhatikan masalah etika penelitian meliputi penjelasan dan persetujuan (Informed consent), menghormati privasi dan kerahasiaan subjek (respect for privacy and confidentiality), menghormati keadilan dan inklusivitas (respect for justice inclusiveness), memperhitungkan manfaat dan kerugian yang ditimbulkan (balancing harm and benefits),

\section{Hasil}

Berdasarkan pengkajian yang telah dilakukan pada tanggal 15 Juni 2019 didapatkan data Tn."A" berusia 75 Tahun, beragama islam , pendidikan pensiunan karyawan BUMN. Status kesehatan Tn.A tekanan darah normal 130/80 $\mathrm{mmHg}$, dan sering merasakan sakit pada persendiannya terutama pada bagian ektermitas bawah. Klien sudah menderita penyakit Rheumathoid Arthritis sudah kurang lebih 2 tahun, Tn."A" mengatakan nyeri dirasakan seperti tertusuk-tusuk. Dari pengkajian riwayat keluarga Tn."A" didapat hasil bahwa tidak ada riwayat penyakit Rheumathoid Arthritis, penyakit keturunan seperti diabetes mellitus, hipertensi, asma, jantung, serta penyakit menular seperti 
HIV AIDS, TBC dan Hepatitis pada anggota keluarga Tn."A". adapun data subjektif yang didapatkan yaitu Tn."A" mengatakan nyeri pada persendian sampai ke ektermitas bawah dan keluarga Tn."A" khususnya Tn."A" mengatakan tidak terlalu memahami masalah kesehatan yang dialaminya. Data objektifnya Tn."A" Nampak tidak bisa menggerakkan dan terasa nyeri pada persendian khusunya pada ektermitas bawah Keluarga Tn."A" Nampak bingung saat ditanya tentang penyakit yang dialami oleh salah satu anggota keluarganya khusunya Tn."A". dari data tersebut didapatkan diagnosa keperawatan yaitu Gangguan mobilitas fisik akibat penurunan kekuatan otot pada penderita arthritis rheumathoid berhubungan dengan ketidakmampuan keluarga dalam merawat anggota keluarga yang sakit dengan standar kriteria evaluasi: Keluarga mampu mengenal masalah penyakit rheumathoid arthritis keluarga dapat mengedemonstrasikan penjelasan pada keluarga tentang pengertian, tanda dan gejala serta perawatan pada rheumarhoid arthritis, Keluarga mampu mengambil keputusan yang tepat untuk mengatasi masalah rheumathoid arthritis, Keluarga mampu merawat Ny."A" yang menderita rheumathoid arthritis, Keluarga mampu menciptakan lingkungan yang sehat, Keluarga mampu memanfaatkan kesehatan apabila ada anggota keluarga yang sakit.

Intervensi berdasarkan diagnose yaitu Observasi tanda-tanda vital pasien, berikan penjelasan tentang pengertian Rheumathoid Arthritis kepada klien dan kepada keluarga klien, berikan latihan ROM pasif dan aktif seperti fleksi dan ektensi jari-jari kaki, beri kompres air hangat pada area yang terkena penyakit rheumathoid arthritis, motivasi keluarga klien untuk mengambil keputusan yang tepat untuk segera memeriksanakn penyakit Rheumathoid arthritis kliem ke puskesmas ataupun ke klinik terdekat, anjurkan pasien untuk tidak memakan makanan yang mengandung lemak tinggi, kaji kemampuan pasien dalam mobilisasi, kaji kemmapuan otot klien, berikan alat bantu jika klien memerlukan, berikan messase atau pijatan lembut pada pasien.

Implementasi berdasarkan rencana tindakan yang telah ditetapkan dan dilakukan selama 3 hari, sehingga didapatkan hasil berdasarkan SOAP yaitu Klien mengatakan nyeri yang dirasakan pada kaki kiri sudah berkurang, keluarga pasien juga sudah memahami apa yang diarahkan oleh peneliti. Keluarga pasien juga mau membantu klien dan selalu mensupport klien saat sakit dengan data objektif yaitu : Klien nampak tidak memegang lagi area yang sakit yaitu kaki kiri yang terkena penyakit rematik yang nyerinya seperti tertusuk-tusuk dan pegal-pegal. Derajat kekuatan otot yang didapati oleh klien adalah dengan skala 1 dengan presentase otot dengan 10 dengan karakteristik tidak ada gerakan, kontraksi otot dapat dipalpasi atau dilihat, dan tingkat kemampuan mobilitas klien adalah tingkat 2 dimana tingkat 2 kategorinya adalah klien masih memerlukan bantuan atau pengawasan orang lain untuk mobilisasi.

\section{Pembahasan}

Berdasarkan hasil pengkajian didapatkan data Tn."A" berumur 75 tahun. Menurut penelitian yang dilakukan oleh Elsi (2018) di Wilayah Kerja Puskesmas Danguang responden yang terdiagnosa RA banyak terjadi pada usia 45-65 dengan prosentase $83,9 \%$ atau 26 responden. Hasil penelitian ini sejalan dengan penelitian Siregar (2016) di Panti Jompo Guna Budi Bakti Medan dengan jumlah responden yang rentan usia terdiagnosa RA $>40$ tahun dengan prosentase 57,37\% atau 35 responden. Dari hasil ketiga persamaan penelitian dapat disimpulkan bahwa usia mempengaruhi terjadinya rheumatoid arthritis. Usia dapat mempengaruhi fungsi dan kemampuan tubuh secara keseluruhan. Pada usia lanjut secara tidak langsung kemampuan jaringan untuk memperbaiki atau mengganti dan mempertahankan fungsi normalnya akan menurun dan mengalami kerusakan, seperti lapisan pelindung pada persendian mulai menipis dan cairan sendi mulai mengental dan kaku saat digerakkan. Biasanya terjadi pada usia. 40 tahun (Ayumar \& Kasma, 2016). Selain itu menurut Nugroho (2010) mengatakan bahwa lansia umumnya mengalami penurunan akibat proses penuaan (aging) dengan adanya penurunan pada fisik, psikologis maupun sosial. Permasalahan pada yang berkembang memiliki keterkaitan dengan perubahan fisik seperti menurunnya kemampuan pada muskuloskeletal menjadi lebih buruk.

Tn.A sering mengeluh merasakan nyeri pada persendian terutama pada ektermitas bawah, klien mengatakan sering merasakan kram dan nyeri pada persendian, sakit yang dirasakan seperti tertusuk-tusuk dan sakit yang dirasakan oleh klien hilang timbul, Hal ini terjadi akibat adanya reaksi auto imun terutama terjadi pada 
jaringan synovial. Proses fagositosis menghasilkan enzim-enzim dalm sendi. Enzimenzim tersebut akan memecahkan kolagen sehingga terjadi edema, proliferasi membrane synovial, dan akhirnya membentuk panus, panus akan menghancurkan tulang rawan dan menimbulkan erosi tulang, akibatnya menghilangkan permukaan sendi yang akan mengganggu gerak sendi. Otot akan turut terkena karena serabut otot akan mengalami perubahan degenaratif dangan menghilangnya elastisitas otot dan kekuatan kontraksi otot. (Lukman \& Nur Nengsih, 2013). Rasa nyeri yang dirasakan oleh penderita reumatoid artritis dari bagian sinovial sendi, sarung tendo, serta bursa yang mengalami penebalan akibat dari radang serta adanya erosi tulang dan destruksi tulang disekitar sendi (Chabib, dkk, 2016). Menurut kesepakatan dari para ahli Rematologi Reumatoid, dari kesepakatan itu disebutkan terdapat tiga keluhan utama pada system musculoskeletal yaitu rasa nyeri, rasa kaku dan kelemahan, serta terdapat tiga tanda yaitu : pembengkakan sendi, kelemahan otot serta gangguan gerak (Idris, 2010). Sendi yang biasa mengalami pembengkakan serta kelemahan adalah sendi bagian jari, pergelangan tangan, bahu, lutut, dan kaki (Hyulita, 2014). Diagnosa keperawatan keluarga dirumuskan berdasarkan masalah keperawatan yang didapat dari data pada pengkajian komponen diagnose meliputi problem atau masalah, etiologi atau penyebab, dan sign atau tanda yang selanjutnya dikenal dengan PES (Problem atau masalah, etiologi atau penyebab), sign atau tanda. Tipologi dari diagnosa keperawatan keluarga aktual (terjadi defisit/gangguan kesehatan), resiko (ancaman kesehata), potensial (keadaan sejahtera). Diagnosa keperawatan keluarga yang muncul pada data diatas yakni Gangguan mobilitas fisik akibat penurunan kekuatan otot pada penderita arthritis rheumathoid berhubungan dengan ketidakmampuan keluarga dalam mengenal masalah.

Perencanaan keperawatan keluarga terdiri dari penetapan tujuan yang mencakup tujuan umum untuk mengatasi masalah pada individu yang sakit dan tujuan khusus untuk memecahkan masalah dengan mengacu pada 5 tugas dalam keluarga dalam hal kesehatan/keperawatan tujuan khusus yang ditetapkan. Rencana keperawatan dengan tujuan setelah dilakukan tindakan keperawatan selama $2 \times 24$ jam diharapkan pasien bisa melakukan aktivitas seperti biasanya.
Intervensi yang dibuat berdasarkan diagnosa keperawatan adalah adalah kaji kemapuan persendian dan mobilitas yang rasionalnya untuk membantu kebutuhan fisik mobiltas pasien secara mandiri sesuai kemampuan. Ajarkan pasien bagaimana merubah posisi dan berikan bantuan jika perlu yang rasionalnya untuk pasien mampu berpindah tempat ke tempat yang lain.

Implementasi keperawatan keluarga merupakan pelaksanaan dari rencana asuhan keperawatan yang telah disusun oleh perawat bersama keluarga. Extended family (keluarga inti) pelaksanaan pemberian asuhan keperawatan keluarga adalah perhatian. Jika perawat tidak memiliki falsafah untuk memberikan perhatian maka tidak mungkin perawat dapat melibatkan diri bekerja sama dengan keluarga. (Susanto, 2012). Setelah diberikan tindakan keperawatan selama 3 hari yaitu klien sudah mampu latihan ROM pasif dan aktif klien sudah bisa menggerakkan kaki kirinya yang terkena penyakit Rheumathoid Arthritis (rematik) seperti Klien sudah bisa fleksi dan ekstensi jari-jari kaki, Fleksi dan ekstensi pergelangan kaki, Rotasi pangkal paha.

Setelah diberikan tindakan keperawatan selama 3 hari, masalah nyeri klien belum teratasi tapi sudah mulai berkurang dan sudah ada peningkatan pergerakan.

\section{Kesimpulan}

Perawatan kesehatan keluarga adalah tingkat perawatan kesehatan masyarakat yang ditujukan atau dipusatkan kepada keluarga sebagai unit atau kesatuan yang dirawat dengan sebagai tujuan utama melalui perawatan. Proses keperawatan adalh metode ilmiah yang digunakan secara sistematis untuk mengkaji dan menentukan masalah kesehatan dan keperawatan terhadap keluarga sesuai dengan rencana yang telah disusun dan mengevaluasi hasil asuhan keperawatan. Data yang dikumpulkan berdasarkan hasil pengkajian didapatkan data bahwa keluarga Tn.A tidak mampu mengenal masalah. Sehingga diberikan implementasi sesuai intervensi yang telah ditetapkan selama tiha hari, dan hasilnya menunjukkan bahwa keluarga Tn.A mengerti terhadap penjelasan yang diberikan namun, belum mampu melakukan aktivitas secara mandiri akibat rasa nyeri yang dirasakan pada akki sebelah kiri. 


\section{Ucapan Terima Kasih}

Terima kasih kami ucapkan kepada ibu Ratna Mahmud, S.Kep., Ns., M.Kes selaku Kepala Prodi Diploma III Keperawatan Fakultas Kedokteran Dan Ilmu Kesehatan Unismuh Makassar serta Kepala Puskesmas Tamalate Kota Makassar, khususnya perawat pelaksana atas bantuannya selama pelaksanaan penelitian.

\section{Referensi}

Amin Huda Nurarif, S. K. (2015). Aplikasi asuhan keperawatan berdasarkan diagnosa medis dan nanda nic-noc. Yogyakarta : MediAction.

Aspiani, R. Y. (2014). Buku Ajar Asuhan Keperawatan Gerontik Aplikasi Nanda, NIC dan NOC Jilid 1. Jakarta Timur:

CV. Trans Info Media.

Ayumar, A., Kasma, A.Y. (2016). Faktor-Faktor Yang Berhubungan Dengan Kejadian Arthritis Rheumatoid Pada Lansia Di Puskesmas Tompobulu Kabupaten Gowa. Sekolah Tinggi Ilmu Kesehatan Makassar: Jurnal Mitrasehat Vol VI No 1.

Elsi, M. (2018). Gambaran Faktor Dominan Pencetus Arthritis Rheumatoid Di Wilayah Kerja Puskesmas Danguang Danguang Payakumbuh Tahun 2018. Akademi Keperawatan Bairurrahman Padang. Menara Ilmu Vol XII. No.8.

Lukman. (2013). Asuhan Keperawatan Pada Klien Dengan Gangguan Sistem Muskuloskeletal. Jakarta: Salemba Medika.

Nugroho, W. (2008). Keperawatan Gerontik dan Geriatrik Ed.3. Jakarta: Buku Kedokteran.

Padila. (2012). Buku ajar: Keperawatan Keluarga Dilengkapi aplikasi kasus Askep Keluarga Terapi Herbal dan Terapi Modalitas. Yogyakarta: Nuha Medika.

Siregar, Y. (2016). Gambaran Faktor-faktor Yang Berhubungan Dengan Kejadian Arthritis Rheumatoid Pada Lansia Di Panti Jompo Guna Budi Bakti Medan Tahun 2014. Stikes Imelda Medan:
Jurnal Ilmiah Keperawatan IMELDA Vol II No.2.

Tantut Susanto (2012). Buku Ajar Keperawatan Keluarga Aplikasi Teori Pada Praktik Asuhan Keperawtan Keluarga. Jakarta: Trans Info Media. 